introduction of cultivation in the neighbourhood of the Great Salt Lake of North America has increased the rainfall, and causer the level of the lake to rise. JosEpH JoHn MURy

\section{Antedon rosaceus (Comatula rosacea)}

Trre communication from Major Fred. H. Lang in NATURE, vol. xiv. p. 527 , as to the abundant canture of Comatula rosacen in Torbay by himself and Mr. Hunt with the dredge during last month, is a valuable contribution to the study of the question of the appearance and disappearauce of certain marine animals in certain localities respecting which we know so little. It is specially interesting to the Birmingham Natural History and Microscopical Society, and as president of the Society and reporter during the marine excursion to Teignmouth in 1873 , aliuded to by iIajor Lang, I must : y that I read it with very great surprise and pleasure. My knowledge of the locality has extended over a period of about thirteen years, and during that time I have on several occasions dredged the ground which he mentions, and never once succeeded in taking an adult specimen of the rosy feather star, much less the more interesting pedunculate form of it. I have not, however, dredged there since our marine excursion. Mr. Gosse, whose experience is very large, and who resides in the neighbourhoud, to whom I showed our mounted specimens, had never before seen the animal in that form, and there is no mention made of the aduli animal in any of his descriptive works except in " $\Lambda$ Year at the Shore," where at p. I 82 he states, "We sometimes but very rarely find on this coast a very lovely form of this class of animals.

Comatula rosacen, a fine specimen of which, taken by myself in a little cove near Torquay, I have delineated." This was written in I864. In the year previously, I believe, Prof. Allman dredged the same locality, and communicated to the Royal Society of Edinburgh a paper "On a pre-brachial stage in the develop. ment of Comatula," founded on a single specimen which he took on the occasion. It is a most remarkable circumstance, therefore, that in the space of about three years the species should have hecome numerous to the extent alluded to by Major Lang, more than a hundred being taken in one haul of the dredge! The marine naturalist who year by year finds his favourite speciniens disappearing on nany parts of the coast, will derive some consolation from Major Lang's communication as a set-off to disappointmerats elsewhere. I notice that Major Lang uses-as I did in 1873 - the nomenciature, Comatulla yo: rcea of Lamarck. Will he torgive me intorming hirn of what $I$ was then ignorantthat Ir. Carpenter, revering to lhe previous designation of Fréninville, has adopred Antelon poscetr-and at the same time directing his attention to the two wonderful and exhaustive monographs on the animal in the Philosopizical Transactions:(1) "On the Embryogeny of Antedon rosaceus," iy Sir Wyville Thomson, at page 5I3, for the year 1865 , and (2) "Researches on the Structure, Playsiology, and Developnent of Antedon rosaccus, "by Dr. Carpenter, at page $67 \mathrm{I}$, for the year $\mathrm{I} 866$ ?

Birmingham, October 20

W. R. HUGIIES

\section{Caterpillars}

$T_{5}$ the experiment related below has never been made before, it appears to me deserving of notice in reference to instinct and evolution. The cuccessful result of the experiment in a singie case last year led me to repeat it on a somewhat larger scale this autumn. On September 25 I placed a number of the caterpillars of Preris brassica in boxes, and fed them with cabbage till they began to spin up. As soon as they had attached themselves by the tail and spun the suspensory girdle, and therefore before the exclusion of the chrysalis, I cut the girdle and caused them to hang vertically by the tail in the manner of the Suspensi. Mo:e than half of the caterpillars had been ichneumonized, and some accidents to the others finally reduced the number in which the experiment was fairly tried to eight. Of these, three came out successfully, the chrysalids maintaining their hold of the caterpillar-skin until they had succeeded in fastening themselve by their anal hooks to the silk to which the caterpillars were attached The other five, as might have been expected of all, fell to the ground for want of the suspensory girdle. Counting the case last year, here then are no less than four out of nine caterpillars of the Succincti, when artificially placed in the conditions of the Suspensi, adapting tremselves to circumstances so great'y changed, and whether by plasticity of instinct or reversion to ancestral habit accomplishing a very difficult operation no less successfully.

Milford, Letterkenny, October I4

\section{Electro-Capillary Phenomena}

THE electro-capillary machine of Lippmann and his capillary electromettr, besides the capillary electroscope of Werner Siemens and the electro-chemical relay of Wheatstone are all iilustrations of a phenomenon resulting from application of an electric current. I am not aware that the converse phenomenon is so generally known, namely, that the motion of the mercury in the tube produces an electric current. If we substitute a galvanometer for the battery in a Lippmann capillary itachine and move the lever by hand, the galvanometer needle is deflected. Similarly, if in any of the electro-capillary electrometers a galvanometer is substituted for the battery and the bubble caused to move by mechanical action, electrical currents are produced which deflect the galvanometer needle.

The fullowing small insurument may serve to show tiris action for lecture purposes :- $a a$ is a glass tube of any convenient bore, say 15 to 20 millimetres, by $300 \mathrm{~mm}$. length ; $b$ is a cork fitting tightly into the middie of the tube, and perforated in two places where are inserted-at $c$ a tube of $\frac{1}{2} \mathrm{~mm}$. bore, slightly longer than the cork is thick, and at $d$ a longer tube, extending half way into both compartments. The ends of the tube $a a$ are stopped by the corks $c e$ through which pass the platinum wires $f g$. Sufficient mercury to quarter fill each compartment is introduced into the tube $a a$, with a small quantity of diluted sulphuric acid. The apparatus being now sealed up, the wires $f$ and $g$ are connected to the termixals of a somewhat delicate galvanometer.

By inverting the tube, as is done with an hour or egg-glass, a current flows through the galvanometer so long as any mercur xuns allerough the tube $c$ (the tube $d$ is an air-tube simply). Reinverting the tube gives a current in an opposite directlon, the platinum wire from that compartment from which the mercury flows always being the zincode of the electrical system. The current decreases with the mercury in the upper chamber as it falls, being a maximum with greatest head of mercury, and falling to

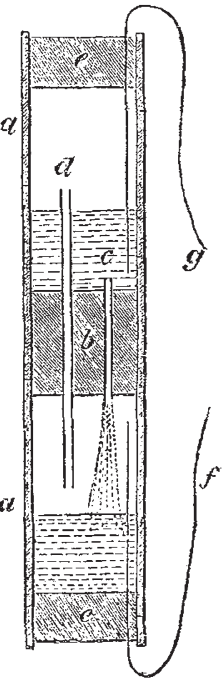
nothing when all the mercury has dropped througli. By any arrangement raaintaining a constant head of mercury a constavit current may be maintained.

Such an apparatus is especially useful in an electrical laboratory where weak currents are required for the acijustment of delicate galvanometers, or where the heaing effect of currents of greater intensity and quantity are required to be avoided. The apparatus can be made in gliss and hermetically sealed. A tube like the above placed on a stand which will allow it to revolve in a vertical plane, and fitted with a commutator, can be made to give a consiant current in one direction, and is al ways ready to hand.

With a filter fumnel the tabe of which is drawn out to a fine point placed above a vessel containing mercury and acidulated water (wires being led from the funnel and lower vessel to the galvanometer) some interesting results are to be noticed which serve to throw considerabie light on the action in electro-capil. lary apparatus. It wlll be found that when the mercury breats away from the funnel at too great height the mercurial column becomes discontinuous, the circuit is interrupted, and of course no current passes through the galvanumeter; and when the funnel is brought so close to the lower vessel as to give only a continuous column, the current is on short circuit and the galvanometer needle undeflected. There is a point, consequentiy, between these two positions giving a maximum current in the outer circuit, and this is easily found experimentally.

P. HIGGS

THE CAPERCAILZIE IN NORTHUMBERLAND

A SHORT time back an account appeared in a Newcastle paper of the occurrence of the Capercailzie at Lilburn, in the north of Northumberland. Of course it was also stated that the bird had been shot. The account was "descriptive," and the writer evidentiy thought he was noting a fact worth telling, for he had 
" reason to believe that this is the first specimen of a wild Capercailzie which has been shot in Northumberland in the memory of man."

Probab!y the writer's glee was somewhat chilled by the appearance in the same paper of an indignant letter from the Earl of Ravensworth, stating that the bird was reared in his park at Eslington from eggs sent from the Highlands, in the hope of naturalising the species in our country; the bird had strayed from its home.

All naturalists-and especially such as know this noble bird in its northern home-must hope that Lord Ravensworth will not be discouraged by this mishap, nor by others like it, but that he will persevere in his experiment. Eslington Park is situated in the valley of the Aln, near the foot of the Cheviots. Perhaps this is not the best part of the country in which to xear the birds, as, although not devoid of timber, the woodland there is scarcely that most suited to the Capercailzie. Pine woods on rocky ground are probably the best. Not far from Eslington, and partly on the Ravensworth estates, there is a superb piece of woodland and crag. Thrunton Crags, and the adjoining crags of Callaly, are very little known except to those who live near them, for they are out of the usual tourists' routes. But in all the county we do not know a district better worth a visit, nor one which so closely resembles the fir-clad mountain sides of southern Norway. The rocks are craggy sandstones, whilst those of Norway are mostly bosses of schists, and there is none of the water which gives such a charm to Norwegian scenery, but, in spite of these differences, the other resemblarces point out this as the Capercailzie's fitting home.

A wide area of high sandstone moorland stretches through Northumberland, attaining a height of over $I, 4,00$ feet at Simonside, near Rothbury, and approaching $I, 000$ feet in other places. This runs to the west of Alnwick, and thence north-west to Chillingham and away towards the Tweed. Another similar district branches from that of Simunside and spreads over a wide area around Harbottle, and between the Coquet and the Reed. Of the first-named range the crags of Thrunton and Callaly form conspicuous features. Only a small part of this range is wooded. It is much to be wished, for the sake of the springs and streams, that plantations were more numerous; and for many reasons, artistic and otkers, we could wish the same. In such parts of these wild hills as fir plantailons occur, the Capercailzie should do well; and, as plantations increase, we might hope that the birds would here find a permanent home. Besides the crags of Thrunton and Callaly we may note, as districts especially well suited to them, the fir woods of Harbottle; parts of the Duke of Northumberland's extensive park at Alnwick; and the wild forest-like park at Chillingham, the home of the far-famed "wild cattle." In years to come, when the plantations increase, Sir W. Armstrong's grounds at Cragside, near Rothbury, will afford the birds a shelter. Here, amidst a profusion of sub-Alpine plants, the Capercailzie should be quite at home.

W. TOPLEY

\section{NEWTON ON FORCE} $\mathbb{M}$ ANY English mathematicians are in the habit not sense-briefly, as cause of change of motion-but of regarding all other senses as loose and inaccurate. Of late years there has been an increasing tendency, largely due to Sir W. Thornson and Prof. Tait, to return to the methods of expressing dynamical principles used by Newton; so that at the present time his statement of the laws of motion is adopted to the exclusion of others which had usurped its place. This return to Newton has led to a very prevalent notion that for all the statements of fundamental dynamical principles current in modern English mathematical literature, we have his authority, and in particular for the above-mentioned restriction of the use of the word "force." As the authority of Newton seems to me to be here claimed without warrant, and as Newton's conception of force cannot be without interest, I propose to examine as briefly as possible what this conception was. In doing so I shall assume that the English word "force" is the equivalent of Newton's Latin word vis.

Newton commences the Principia with eirht definitions, among which are definitions of the intrinsic force of matter (zis insita or vis incrtia), impressed force, and centripetal force; he then proceeds to state and explain the laws of motion. From the chapters on the definitions and the laws of motion, we are able to infer with much probability the sense in which the word "force" is used. To show this it will only be necessary to translate a few extracts.

"Def. III.-The intrinsic force of matter is its power of resistance, by which every body, as far as depends on itself, persists in its state either of rest or of uniform rectilinear motion."

"Def. IV.-An impressect force is an action exerted on a body towards changing its state either of rest or of uniform rectilinear motion."

"Def. V.-A centripetal force is one by which bodies are pulled, pushed, or in any way tend from all parts towards any point as a centre."

"Just as in cases of impact and rebound bodies are equipollent whose velocities are reciprocally as their intrinsic forces; so in moving mechanical instruments agents are equipollent, and mutually support each other by their contrary efforts, whose velocities, estimated in the direction of the forces, are reciprocally as the forces." (Scholium to the Laws of Motion.) In the latter part of this quotation the word "forces" is used in the sense of impressed forces as defined by Def. IV.

One more quotation must be made; it is from Newton's comment on Def. III.: "-but a body exerts this force [vis inertia] only while a change is being made in its state by another force impressed on it."

In the quotaition from the Scholium, Newton is considering two cases in which bodies are to be moved; in one the power of resisting the motion arises from the intrinsic force of the body (or its wis inertice), in the other from the impressed force; in each case he seeks a measure of the effort required to move the bodies. Newton argues that, in the first case, this is to be measured by the intrinsic force and velocity conjointly, and in the second by the impressed force and [virtual] velocity conjointly ; implying that, in the first case, to give a body a certain velocity is equivalent to giving a body of twice its intrinsic force half that velocity; and in the second case-to take an example-that to lift a body vertically at a certain rate is equivalent to lifring a body of twice its weight at half the rate.

In this Scholium, in the case both of intrinsic force and of impressed force, the word "force" indicates some power of resistance to change of state; a general power due to the intrinsic force, and a special power due to the impressed force. And throughout it will be found that Newton's use of the word in its most general sense indicates a power of resistance, which professed metaphysicians are not alone in attributing to matter as essential to the conception of it. This most general sense of the word does not prevent Newton using it in any one of its special senses, and in particular very frequently for $i m$ pressed force, where no confusion is likely to arise ; but his language is very far from sanctioning the dictum that this is the sense and the only sense in which the word "force" may be used.

It is painful to refiect that Newton, great as he undoubtedly was, does not seem to have been sufficiently advanced to doubt whether there is such a thing as force, nor to have had a proper sense of the heinousness of his conduct in writing of accelerative force, motive force, and -worst of all-centrifugal force $\quad$ P. T. MAIN 